\title{
Humor or Black Humor? The Use of Humor and Irony in The Financial Expert
}

\author{
Abel Justine \\ Post Graduate \\ St. Joseph's College (Autonomous) \\ Devagiri, Calicut, Kerala, India \\ abeljustine465@gmail.com \\ DOI: https://doi.org/10.24113/ijellh.v9i4.10983
}

Abstract

R. K. Narayan was one of the pioneers of Indo Anglian fiction along with Mulk Raj Anand and Raja Rao. Their heydays were marked by complicated social issues such as India's struggle for Independence and the more stressful period afterwards. Among the three, many consider R. K. Narayan as the most realistic in fiction considering Indian settings. The Financial Expert is again considered as Narayan's masterpiece by many. It's a wellconstructed novel in five parts. The story is focused on three main aspects relating to the central character of Margayya. They are; Margayya's determination to acquire wealth, his love for his own son Balu and his relationship with his brother and sister in law. It is at times mesmerizing to analyze Narayan's use of humor and irony in crafting the fate of a normal middle class individual.

Keywords: Life cycle, Social life, Satire, Humor, Irony

Humor or Black Humor?

The Financial Expert portrays the social life of the Indian middle class with a farcical touch. The tension between the two brothers in it for family property is an example. 
Margayya and his brother's family are divided by a wall which stands across the house. The sister-in-laws are obviously at odds against each other and each tries to spy on the other. Despite the quarrels, the two families join at significant points in the novel.

The very title of the novel is ironic because Margayya means someone who shows the way. But here, Margayya is concerned about his own financial status. He wants to be rich but for which, he seeks the help of others like Dr. Pal who is a quack. A financial expert to others ends up a failure in his own life.

Margayya's efforts in shaping the future of his son is another plate of satire. Narayan satirizes the educational system of India through this strategy. Just to make his dull-witted son pass the matriculation, Margayya manages to get into the governing body of the school and tries to keep the teachers under his control. The relationship between Balu and his home tutor is simply a mockery of the sacred student-teacher relationship.

Indian marriages as portrayed by Narayan are far from idealistic. He satirizes the way marriages are fixed. The astrologer speaks in favor of a relationship when he is paid more. The caste and profession of a great grandfather is a pivotal factor in a marriage today. Margayya's great grandfather is a corpse bearer and he is worried that people will remember this when marriage alliances come up for his son Balu.

Dr. Pal is an ironic villain in the story. Although an unmarried man, he has written a pornographic book on marital happiness. He declares that he is a man who works for mankind but his actions in the novel prove otherwise. He spoils the marital life of Balu and Brinda by introducing Balu to the world of clubs and whores. He who helps Margayya by fetching clients for his business turns out to be one of the main reasons for Margayya's downfall as well.

Margayya is quiet ignorant on a number of things but he tries to conceal his ignorance which leads to farcical consequences. He doesn't know the story of Markandeya but pretends 
to know it. He doesn't mean the term 'sociology'. He is totally ignorant of the techniques involved in printing, yet he pretends he knows enough about it.

“All Mr. Narayan's comedies have had this undertone of sadness."(qtd in Warner)Graham Greene opined about Narayan's work. Here lies the key point that all the humorous portrayals of Narayan have a touch of inevitable pathos in them. They are all moral tales about human life and fate. It is simply the mode of craft that makes them entertaining. The ironic point that a fortune can be destroyed in a moment by nothing but a rumor sheds a darker shade on the theme of the novel.

There is hence an underlying sadness in Margayya. Even at the peak of his success, he betrays a pathetic helplessness of a fond father. Margayya's weaknesses are subject to moral judgment by Narayan but with a sympathetic understanding of life's predicament. As a result, the bitter string of irony is reduced to a mild disapproval of tragi-comic touch. Conclusion

Narayan provides his philosophy of life and wealth through these farcical situations. Regarding people's belief in poojas, the priest says, "The result cannot be our concern. It's karma" (Narayan, 26). Margayya is a comic hero who matures from innocence to experience. When the life cycle turns, the whole of his fortune crumbles and life begins with a new set of values. His stupendous rise up the financial ladder demands admiration as well as censure. Money starts as a problem which later grows into an obsession and then to a perversion. Margayya's ethical degeneration born out of his inflated ego leads to his downfall through the moral corruption of his spoilt son.

This downfall is partly brought by Balu's reckless lifestyle which Margayya's traditional perspective on life cannot approve. But he has long since followed the modern materialistic approach for his own progress. This comic incongruity marks the character of 
Margayya. He gets back to his old and original position by the end of the novel but chastened by his experience, gaining wisdom. 


\section{Works Cited}

Narayan, R. K. The Financial Expert.Chicago: The University of Chicago Press, 1981. Print.

Warner, Reese. "Typings: The Painter of Signs.” ReeseWarner.Blogspot, 26 March 2019, http://reesewarner.blogspot.com/2019/03/the-painter-of-signs.html. Accessed 27 March 2020.

Note: Paper Checked. Correction Done. 